\title{
Correction to: A common gene drive language eases regulatory process and eco-evolutionary extensions
}

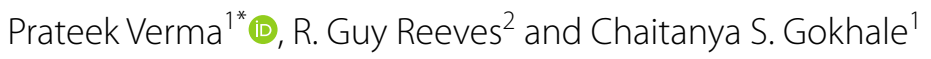

\section{Correction to: BMC Ecol Evol (2021) 21:156} https://doi.org/10.1186/s12862-021-01881-y

Following the publication of the original article [1], we were notified that Figs. 1, 3, 4 were incomplete.

- Originally published figures:
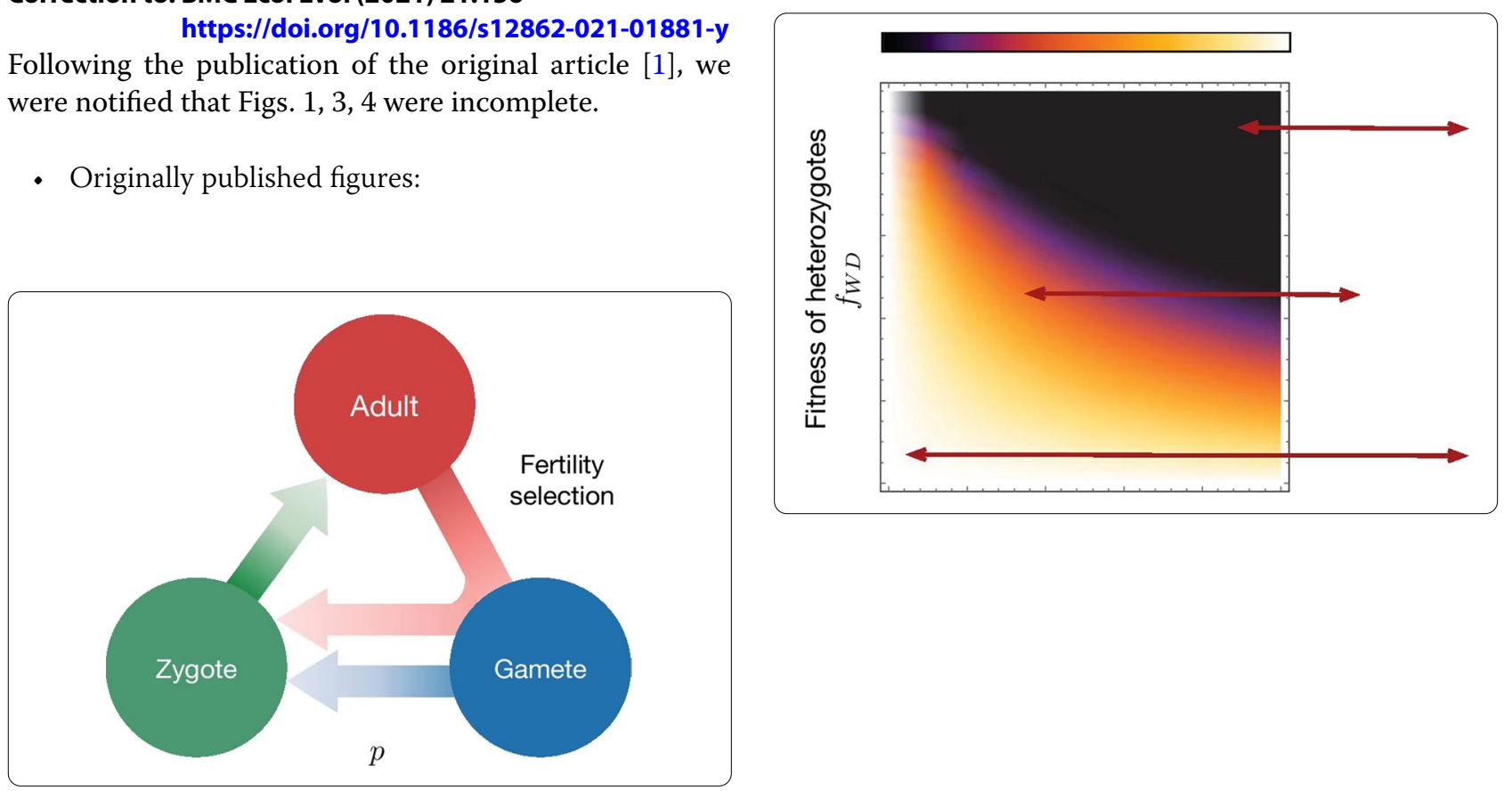

The original article can be found online at https://doi.org/10.1186/s12862021-01881-y.

\footnotetext{
*Correspondence: verma@evolbio.mpg.de

${ }^{1}$ Research Group for Theoretical Models of Eco-evolutionary Dynamics, Department of Evolutionary Theory, Max Planck Institute for Evolutionary Biology, Plön, Germany

Full list of author information is available at the end of the article
} 

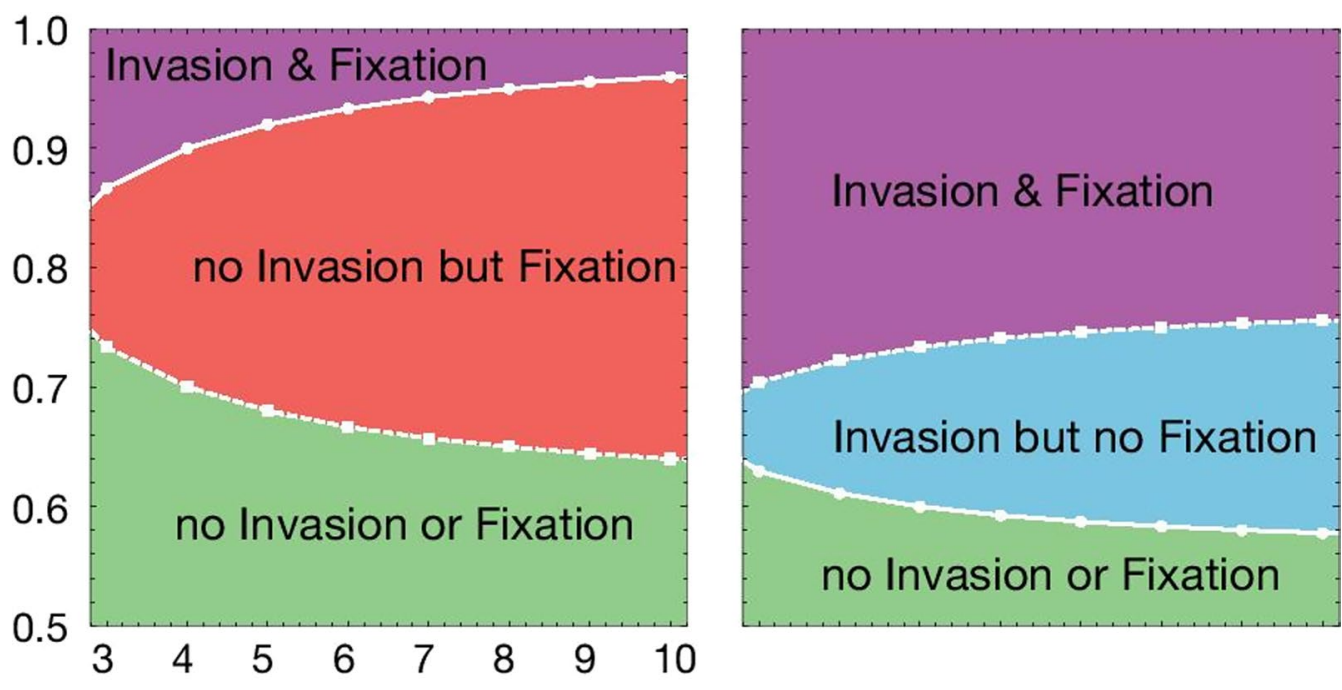

\section{Network degree, $k$}

- Corrected figures (Figs. 1, 3, 4):

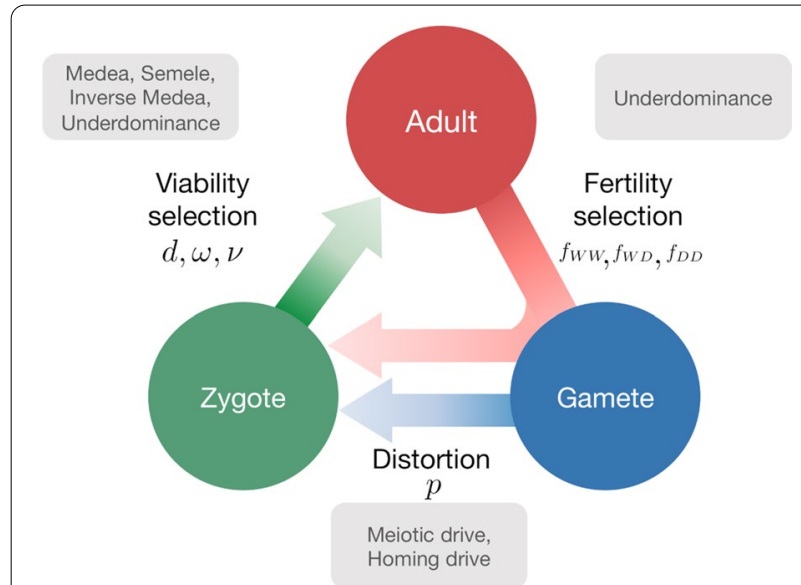

Fig. 1 Lifecycle of an individual organism for a generic gene drive model. Assuming that individuals reproduce sexually and that the lifecycle has three stages, Adult, Gamete and Zygote. Adults produce gametes which combine to form zygotes. Zygotes grow up to become adults. Three factors can act during the life stages of an organism: distortion, viability selection and fertility selection (represented as arrows). Each can influence the probability of inheritance of a gene in the population and can be potentially manipulated to engineer gene drive constructs. Parameters, described in the text, are associated with each of the three arrows. Examples of named drive systems that can be generated are provided associated with the respective arrow

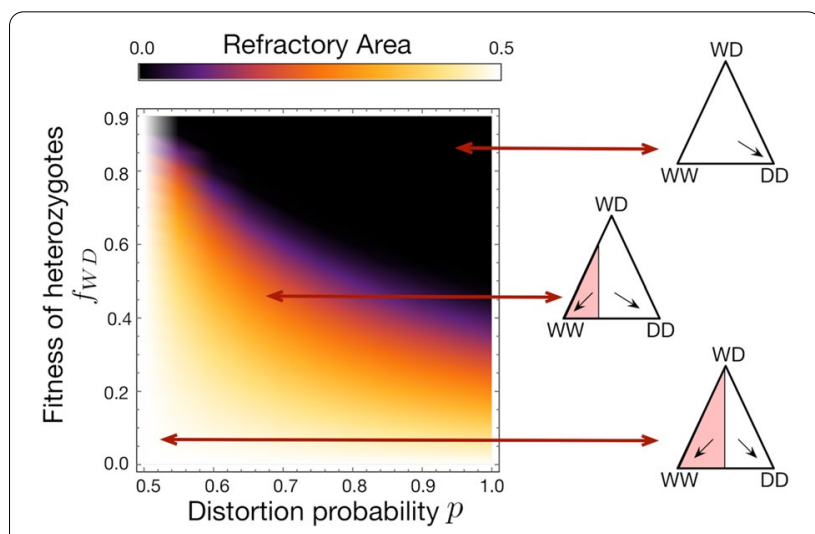

Fig. 3 Heat-map showing the refractory zone with variation in distortion probability $p$ and fertility fitness of heterozygotes $f_{W D}$. Illustration of refractory zone for specific values of $p$ and $f_{W D}$ of the heat-map. Trajectories of a de Finetti diagram when $2 p f_{W D}>f_{W W_{1}}$ drive individuals invade the wild population. Refractory zone is zero and is shown by black colour in the heatmap. $p=0.5$ corresponds to'no distortion' case. The values of other parameter is fixed to $f_{w W}=1$, $f_{D D}=1$ 


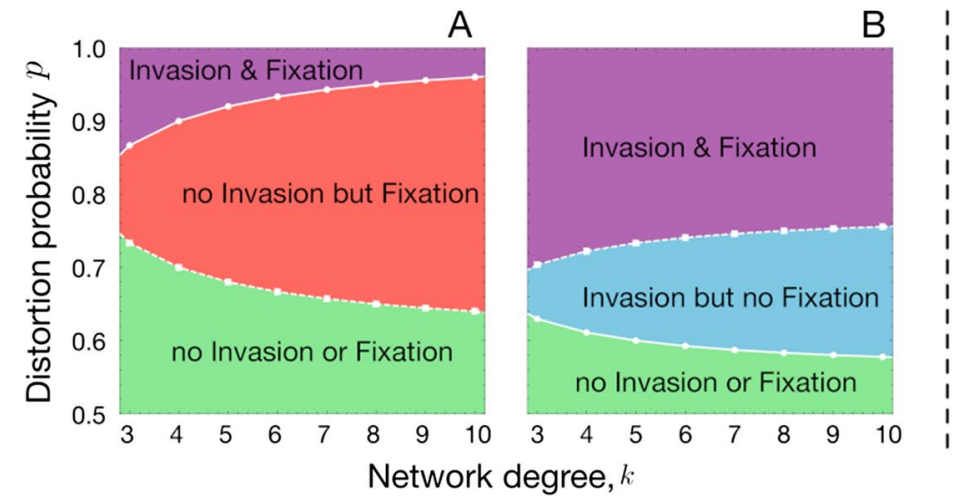

\section{Spatial \\ representation}

Example network for Example network for

$$
k=4 \quad k=10
$$
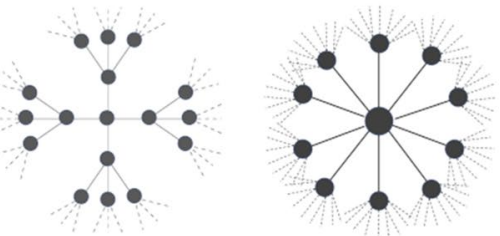

As $k \rightarrow \infty$

well-mixed population

Fig. 4 Spatial structure affects the condition for the invasion from rare and fixation of the driven gene. A Variation in invasion (full line with circles) and fixation (dashed line with squares) conditions with respect to network degree ( $k$ ) and distortion parameter $(p)$ for $f_{W D}=0.5$ and $\mathbf{B} f_{W D}=0.9$. The values of other parameters are fixed to $f_{W W}=1, f_{D D}=0.4$. Population dynamics changes when the population becomes more structured on the Bethe lattice parameterized by $k$. Lower $k$ means more structured population and higher $k$ represents less structure (closer to well-mixed case). The change in population dynamics properties can be seen by the change in invasion/fixation condition and combinations of them, such as no invasion from rare but fixation, if sufficient drive individuals are released/migrate

The original article has been corrected.

\section{Author details}

${ }^{1}$ Research Group for Theoretical Models of Eco-evolutionary Dynamics, Department of Evolutionary Theory, Max Planck Institute for Evolutionary Biology, Plön, Germany. ${ }^{2}$ Department of Evolutionary Genetics, Max Planck Institute for Evolutionary Biology, Plön, Germany.

Published online: 25 October 2021

\section{Reference}

1. Verma P, Guy Reeves R, Gokhale CS. A common gene drive language eases regulatory process and eco-evolutionary extensions. BMC Ecol Evol. 2021;21:156. https://doi.org/10.1186/s12862-021-01881-y.

\section{Publisher's Note}

Springer Nature remains neutral with regard to jurisdictional claims in published maps and institutional affiliations.
Ready to submit your research? Choose BMC and benefit from:

- fast, convenient online submission

- thorough peer review by experienced researchers in your field

- rapid publication on acceptance

- support for research data, including large and complex data types

- gold Open Access which fosters wider collaboration and increased citations

- maximum visibility for your research: over 100M website views per year

At BMC, research is always in progress.

Learn more biomedcentral.com/submissions 